\title{
Staphylococcus aureus Toxins and Their Molecular Activity in Infectious Diseases
}

\author{
Diana Oliveira ${ }^{(1)}$, Anabela Borges ${ }^{(1)}$ and Manuel Simões * \\ LEPABE, Department of Chemical Engineering, Faculty of Engineering, University of Porto, Rua Dr. Roberto \\ Frias, s/n, 4200-465 Porto, Portugal; dianarosalopesoliveira@gmail.com (D.O.); apborges@utad.pt (A.B.) \\ * Correspondence: mvs@fe.up.pt
}

Received: 30 April 2018; Accepted: 15 June 2018; Published: 19 June 2018

\begin{abstract}
Staphylococcus aureus is a microorganism resident in the skin and nasal membranes with a dreadful pathogenic potential to cause a variety of community and hospital-acquired infections. The frequency of these infections is increasing and their treatment is becoming more difficult. The ability of $S$. aureus to form biofilms and the emergence of multidrug-resistant strains are the main reasons determining the challenge in dealing with these infections. S. aureus' infectious capacity and its success as a pathogen is related to the expression of virulence factors, among which the production of a wide variety of toxins is highlighted. For this reason, a better understanding of $S$. aureus toxins is needed to enable the development of new strategies to reduce their production and consequently improve therapeutic approaches. This review focuses on understanding the toxin-based pathogenesis of $S$. aureus and their role on infectious diseases.
\end{abstract}

Keywords: biofilms; epidemiology; exfoliative toxins; pore-forming toxins; Staphylococcus aureus; superantigens

Key Contribution: This review analyzes the mechanisms of toxin production by S. aureus and describes their molecular activity in infectious diseases.

\section{Introduction}

S. aureus is an opportunistic human pathogen known to colonize the respiratory tract of approximately $30 \%$ of the U.S. population [1,2]. S. aureus infections range in severity from mild skin infections to severe necrotizing pneumonia. It is simultaneously the leading cause of bacteremia, infective endocarditis (IE), and can also cause osteoarticular, skin and soft tissue, pleuropulmonary, and device-related infections [3]. Vancomycin is commonly used to treat these infections as this antibiotic is active against both methicillin-resistant and methicillin-susceptible S. aureus strains (MRSA and MSSA). However, over the years the emergence of resistant strains to antimicrobials has been reported, the main reason why these infections are becoming more difficult to treat [4,5].

S. aureus can express a variety of resistance mechanisms and virulence factors, allowing it to evade host natural defenses [6]. Among the multiple virulence factors produced by this microorganism, it is possible to enumerate toxins, enzymes and cell surface-associated antigens [6]. Toxins can lead to a weak response by the colonized organism since they are able to degrade some of the host cells, manipulate the innate and adaptative immune responses, and degrade inter-cellular junctions, which has an obvious contribution in S. aureus proliferation [7].

Thus, a strong correlation between virulence genes and certain disease symptoms has been established. For instance, toxins are being strongly suspected to cause diseases such as toxic shock syndrome (TSS), staphylococcal scalded skin syndrome (SSSS), necrotizing pneumonia, or deep-seated infections [8-12]. This clear association between toxins and some diseases has led to an urgent and 
better understanding of $S$. aureus pathogenesis, etiology, epidemiology, pathophysiology and more precisely its high regulated mechanism of toxin production. Effective preventive approaches will enhance the capacity to control staphylococcal infections, as the tenacity of this microorganism as a pathogen is mainly attributed to its machinery of virulence factors $[13,14]$.

\section{Staphylococcus aureus Etiology, Epidemiology and Pathophysiology}

S. aureus is a major pathogen that causes a wide variety of infectious diseases [3]. This bacterium has a cell wall composed of a single lipid membrane, surrounded by a thick layer of peptidoglycan and lipoteichoic acid anchored by diacylglycerol [15]. Peptidoglycan is the main compound of the staphylococcal cell wall (50\%) and consists of two alternating polysaccharide subunits of $N$-acetylglucosamine and $N$-acetylmuramic acid with 1,4- $\beta$ linkages [16]. The peptidoglycan chains give rigidity to the cell wall, determining its shape and protecting it from osmotic lysis [16]. Another cell wall constituent is a group of phosphate-containing polymers called teichoic acids, which contribute for $40 \%$ of the cell wall mass [17]. Teichoic acids give a negative charge to the staphylococcal cell surface and play a role in the acquisition and localization of metal ions [18]. Together, these two cell wall components account for $90 \%$ of the weight, the remaining $10 \%$ being composed of surface proteins, exoproteins and autolysins [19].

S. aureus was first identified in 1884 by Anton Rosenbach, a German surgeon [20,21]. Rosenbach isolated two strains of staphylococci (S. aureus and Staphylococcus epidermidis) and named them based on the pigmented appearance of their colonies [20]. At the time of this discovery, most of the patients infected with $S$. aureus died, with a mortality rate of near $82 \%$ for patients with $S$. aureus bacteremia [22]. This rate largely decreased after the introduction of penicillin into clinical practice [23]. However, in the early 1940s, the first penicillin-resistant S. aureus strains appeared and by the end of the decade, almost $25 \%$ of the hospital-associated strains were resistant to penicillin [24-26]. Though methicillin and oxacillin were developed to overcome this resistance problem in the 1960s, only one year after their introduction, resistant strains emerged again, designated as MRSA [27]. Therefore, between the 1960s and the 1980s, MRSA hospital-acquired infections become more frequent, and in the 1990s the percentage of infections related to MRSA reached 29\% [28,29]. Since then, it has been shown that contact with patients with MRSA and the receipt of antimicrobials increased the probability of being infected with this microorganism [26,30,31]. However, in the late 1990s, MRSA infections started to be reported in healthy, young patients who had no exposure to a hospital setting [32-35]. Today, hospitalized patients are still the most predisposed to acquire these infections mainly because of their compromised immune system, extended exposure to antimicrobials, and the use of contaminated indwelling devices such as ventilators or catheters [36,37].

Therapeutic options available are typically ineffective due to the strong ability of $S$. aureus strains to develop antibiotic resistance determinants [38]. Thus, the control of bacterial infections requires a deep understanding of intracellular genetics and biochemistry, and profound knowledge on how the biofilm mode of life affects antibiotic action and the development of resistance [38]. Once bacteria are immersed in biofilm, they have community resistance mechanisms distinct from the well-characterized single cell level mechanisms [38]. Bacterial communities exhibit an altered phenotype in terms of growth, gene expression and protein production, and can also exhibit tolerance to environmental stress that single cells cannot $[39,40]$. The matrix of polymeric substances (EPS) that surrounds these bacteria protects from phagocytosis, antibiotics, disinfectants and other components of the innate and adaptive immune and inflammatory systems of the host, and allows the capture of nutrients such as carbon, nitrogen and phosphate, which are essential for the cell [39,41,42].

The multi-layered biofilm produced by $S$. aureus is embedded within an EPS matrix, which is described to be mainly composed of teichoic acids (80\%) and staphylococcal and host proteins [43]. A more detailed EPS characterization identified a polysaccharide intercellular antigen (PIA), also known as polymeric $N$-acetylglucosamine (PNAG) [44]. PIA is composed of $\beta-1,6$-linked $N$-acetylglucosamine 
residues (80-85\%) and an anionic fraction with a lower content of non- $N$-acetylated D-glucosaminyl residues that contains phosphate and ester-linked succinate (15-20\%) [45].

As part of the natural biofilm development cycle, cells within mature biofilms produce compounds that can induce shift from biofilm to a planktonic mode of life [38]. This shift is essential in the process of cell dispersal from biofilms [46]. In S. aureus, biofilm detachment is controlled by the quorum-sensing system Agr [47,48]. This system is suggested to be an important regulatory switch between planktonic and biofilm regimes, contributing to dispersal and colonization of S. aureus in other sites [48]. S. aureus quorum-sensing system is encoded by the accessory gene regulator (agr) locus, and it produces a communication molecule called an autoinducing peptide (AIP) [49]. Once AIP reaches a critical concentration, a regulatory cascade is initiated, and a myriad of virulence factors is expressed. This system consists of two divergent transcripts, RNAII and RNAIII, initiated from two distinct promoters, $\mathrm{P} 2$ and P3, respectively. The P2 operon contains agrBDCA and codes for the RNAII transcript, while P3 drives transcription of the effector molecule of the agr locus (RNAIII) [47,49]. An increase in the transcription of $\mathrm{P} 2$ and $\mathrm{P} 3$ appears to result in a rise of the intracellular concentrations of RNAIII, which in turn, seems also to increase the expression of secreted virulence factors [47].

Many of the secreted S. aureus virulence factors can be described as toxins, as they are usually described as poisonous substances [50]. On the other hand, toxins are distinct from other virulence factors as they are secreted by the producing organism and they directly affect the host [50]. The influence of some toxins in biofilm development has been studied and it has been demonstrated that some of them play a preeminent role in biofilm progress. For example, Scheer et al. demonstrated the influence of Hemolysin- $\alpha$ (Hla or $\alpha$-toxin) and Leukotoxin AB (LukAB) in biofilm persistence [51]. The importance of these toxins was assessed using a murine orthopaedic implant biofilm infection model and revealed a synergistic role of Hla and LukAB in promoting macrophage dysfunction and eliciting cell death. This reduction in macrophage phagocytosis facilitated the ability of $S$. aureus to avoid destructive host responses when organized as a biofilm [51]. Another study demonstrating the influence of toxins in biofilm progression was conducted by Dastgheyb showing that phenol-soluble modulins (PSMs) interfere with biofilm formation by disrupting interactions of matrix molecules with the bacterial cell surface [52]. The interaction of S. aureus surface proteins with host matrix proteins such as fibrin initiates agglomeration and it grows to exceptionally large dimensions due to the lack of PSM expression under the specific conditions of the study [52]. An in vitro study conducted by Periasamy demonstrated similar results with regard to the impact of $S$. aureus PSMs in biofilm formation, as PSMs destructed biofilms and led to its dispersal due to the surfactant properties of the toxin [53].

\section{Staphylococcus aureus Toxins}

The proficiency of $S$. aureus as a pathogen can be attributed to its arsenal of virulence factors among which secreted toxins play an important role $[13,14]$. The main S. aureus toxins can be divided into three major groups-the pore-forming toxins (PFTs), exfoliative toxins (ETs) and superantigens (SAgs). Pore-forming toxins can be further divided into four types-Hemolysin- $\alpha$ (Hla or $\alpha$-toxin), Hemolysin- $\beta$, leukotoxins and phenol-soluble modulins (PSMs) [7]. This system of protein production responds to a wide range of different conditions and understanding this mechanism will allow a better control of staphylococcal infections.

S. aureus toxins are related to some diseases such as toxic shock syndrome (TSS), staphylococcal scalded skin syndrome (SSSS), necrotizing pneumonia or deep-seated skin infections [8-12]. The toxins are capable of damaging the cells membranes of the host, either by degrading inter-cellular connections or by modulating immune responses [7]. 


\subsection{Pore-Forming Toxins}

\subsubsection{Hemolysin- $\alpha$ (Hla or $\alpha$-Toxin)}

Hla is a $33 \mathrm{kDa}$ polypeptide secreted by $95 \%$ of clinical S. aureus strains [6,7]. Hla is a beta-barrel forming toxins secreted as a water-soluble monomer [7,50]. This toxin on its own is not considered toxic, it is its bonding capability and oligomerization into a heptameric structure on the host cell membrane that makes it dangerous [54,55]. When Hla binds to its target cell, it oligomerizes to a pre-pore structure and attacks the cell membrane by extrusion of the $\beta$-barrel through the lipid bilayer to form a hydrophilic transmembrane channel (Figure 1) [56]. This toxin is the prototype for the class of small $\beta$-barrel pore-forming cytotoxins (PFTs) [57-60]. Over the years, pore formation and cellular lysis were considered the most prominent consequence of Hla action. However, recent studies have shown the importance of the alteration of the cell signalling pathways, which includes cell proliferation, inflammatory responses, cytokine secretion and cell-cell interactions [54,55,57-61]. This toxin has been demonstrated to affect a wide range of human cell types, including epithelial cells, endothelial cells, T cells, monocytes, and macrophages [57,62-68].

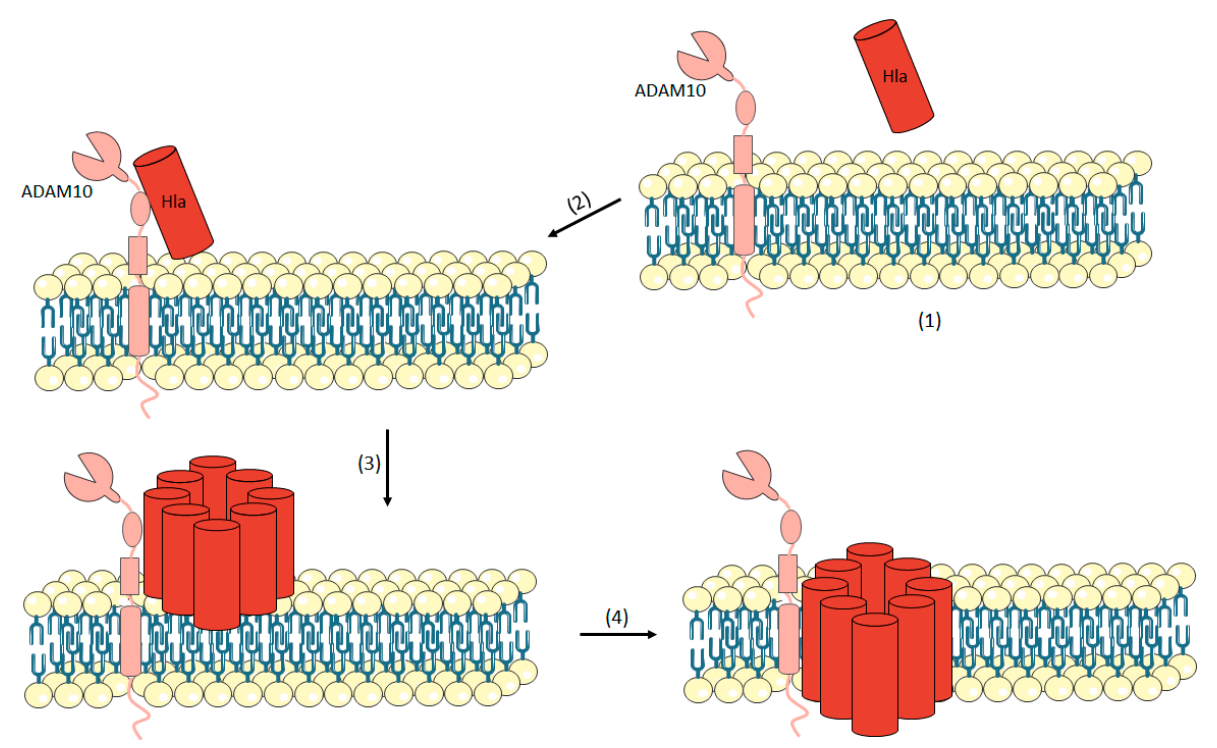

Figure 1. Mechanism of action of Hemolysin- $\alpha$ (Hla). Hla is secreted as a water-soluble monomer (1). Hla binds to the transmembrane protein ADAM10 which is a cellular receptor for $\alpha$-toxin (2). Then, the toxin oligomerizes into a heptamer on the plasma membrane and a pre-pore is formed (3) and, at the end, the formation of the transmembrane channel occurs (4).

Hla induces different signalling events in the target cell, depending not only on the relative concentration of toxin but also on the type of cell exposed [64]. When the toxin approaches the cell, the small pore formed allows rapid release of ATP, $K^{+}$ions, while also restricting the movement of macromolecules across the cell membrane [64,69-71]. After the pore formation step, there is an influx of extracellular calcium into the cell. The increase in the intracellular calcium stimulates hydrolysis of membrane phospholipids and metabolism of arachadonic acid to leukotrienes, prostanoids and thromboxane A2 [72-74]. Then, there is also an activation of the protein Kinase $\mathrm{C}$ and the induction of NF-kB nuclear translocation $[72,74,75]$. All these events together with the production of IL-1 $\beta$, IL-6 and IL-8 signify the pro-inflammatory stimulus. In the epithelial cells, which are key targets of Hla, E-cadherin is a main substrate for ADAM10 [76,77]. ADAM10, a cellular receptor for Hla, is a zinc-dependent metalloprotease expressed as a type I transmembrane protein on the surface of most host cells $[78,79]$. The enzyme that degrades E-cadherin is activated after Hla bond compromising the epithelial tissue barrier function which in turn allows $S$. aureus invasion $[7,80]$. The discovery 
of ADAM10 as a cellular receptor for Hla allows a deeper examination on the effects of the toxin in a specific cell population. It has been verified that this toxin plays an important role in $S$. aureus pathogenesis and there are two evidences reinforcing this hypothesis. The first concerns people who suffer from $S$. aureus disease and develop serum antibody responses to the toxin consistent with the toxin expression [81-83]. The other evidence is regarding bacterial genetic and protein profiling analysis [64]. From analysis of the hla and agr loci of the S. aureus strains involved in epidemic events in the 1950s and 1960s, it was possible to reveal the capability for Hla expression, confirmed by the presence of a high virulent phenotype of these isolates in animal studies of Hla-mediated disease [84]. Together these studies show that the expression of Hla may be required for the pathogenesis of invasive disease in healthy individuals [64].

\subsubsection{Hemolysin- $\beta$ (Sphingomyelinase C)}

Hemolysin- $\beta$ was firstly identified in 1935 by Glenny and Stevens and the sequence of the gene $h l b$ was discovered in 1989 by Projan et al. [85,86]. This toxin has shown to be highly hemolytic towards erythrocytes in sheep, but not in rabbits [8]. The difference in susceptibility for erythrocytes may be due to the different sphingomyelin contents of these cells since the toxin is also known as sphingomyelinase [87]. Sphingomyelinases are phosphoric diester hydrolases that cleave sphingomyelins, the most abundant sphingolipid in eukaryotic membrane [88].

The role of this toxin in disease is not clearly understood. It is known that $\beta$-hemolysin is produced in large amounts in animal isolates and its high expression may indicate that $\beta$-hemolysin producers have some selective advantage from toxin secretion [8]. This toxin is produced in large quantities in strains isolated from bovine mastitis [89] and human skin chronic infections [90]. $\beta$-hemolysin is cytotoxic towards human keratinocytes, polymorphonuclear leukocytes, monocytes, and T lymphocytes and inhibits interleukin-8 (IL-8) expression by endothelial cells. These can contribute to phagosomal escape of $S$. aureus and induction of biofilm formation [90-94].

Some studies have demonstrated the importance of this toxin for $S$. aureus pathogenicity. Virulence of a mutant $S$. aureus strain lacking hlb was reduced in pneumonia and murine ear skin infection models [90,95]. In addition, a mutant strain expressing a biofilm formation-deficient $\beta$-hemolysin had a reduced pathogenicity in an endocarditis model in rabbits [92].

\subsubsection{Leukotoxin}

The pore-forming leukotoxins consist of two different protein components that assemble together to form $\beta$-barrel pores $[96,97]$. So far, it has been isolated from $S$. aureus strains associated to human infections four bi-component leukotoxins that are structurally similar to Hla: Panton-Valentine Leukocidin (PVL), gamma $(\gamma)$-Hemolysin (HlgA, HlgC, HlgB), Leukotoxin ED (LukE, LukD) and Leukotoxin AB/GH (LukAB/LukGH) [98]. These pore-forming toxins consist of two different protein components classified as "S" and " $\mathrm{F}$ ". The S-component confers cell-type specificity by binding to cellular receptors (Table 1) [96-98].

Table 1. Protein subunits "S" and "F" of each leukotoxin and cell specificity [98].

\begin{tabular}{cccc}
\hline Leukotoxin & S Subunit & F Subunit & Cell Specificity \\
\hline PVL & LukS-PV & LukF-PV & Leukocytes and neutrophils \\
\hline Luk AB/Luk GH & LukA/LukH & LukB/LukG & $\begin{array}{c}\text { Human monocytes, dendritic cells, neutrophils } \\
\text { and leukocytes }\end{array}$ \\
\hline$\gamma$-Hemolysin & HlgA, HlgC & HlgB & $\begin{array}{c}\text { Rabbit blood cells and leukocytes, human } \\
\text { neutrophils and mouse phagocytes }\end{array}$ \\
\hline
\end{tabular}


After bonding, a conformational change allowing dimerization with F-components is induced [99]. Then, an oligomerization occurs to form the pre-pore prior to insertion of the $\beta$-barrel transmembrane channel [100]. There is strong evidence corroborating this hypothetical mechanism [101-103]. Miles et al. described the formation of an octameric pore containing four subunits each of LukF and LukS [101]. Further, images of purified $\gamma$-Hemolysin pores on human erythrocyte membranes obtained by electron microscopy were interpreted as heptamers [102]. Additionally, Jayasinghe et al. provided convincing evidences that the Luk pore is an octamer formed by LukF and LukS and assembled on rabbit red cell membranes [103]. These authors also show the existence of four LukF and four LukS subunits [103]. The mechanism of pore formation of these bi-component toxins with the membrane of the cell is shown in Figure 2.

The four leukotoxins lyse cells of the leukotocytic lineage and they also have been known to kill neutrophils, while only $\gamma$-Hemolysin and LukED have demonstrated lytic activity against red blood cells $[98,104,105]$.
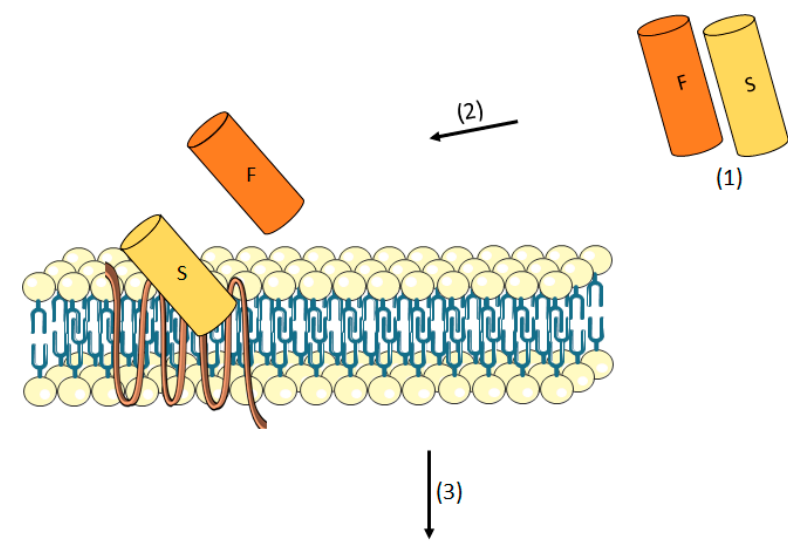

(1)
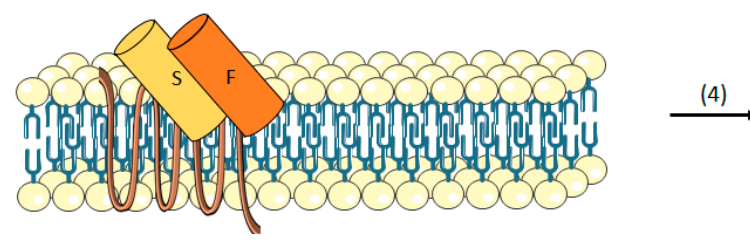

Figure 2. Mechanism of action of leukotoxins. The monomers are secreted (1). The S-component binds the cell surface receptor (2) then, the F component is recruited, and dimerization occurs (3). These dimers oligomerize on the plasma membrane and a pre-pore appears (4). At last, the formation of the transmembrane channel occurs (5).

$\gamma$-Hemolysin (HlgAB/HlgCB)

Within the $\gamma$-Hemolysin group, HlgAB, HlgCB or HlgACB are three proteins with different subunit combinations. HlgAB and HlgCB share the same F subunit (HlgB) but differ in $S$ subunit composition (HlgA or HlgC) [98,106]. HlgA (32 kDa) and HlgC (32k Da) only exhibit lytic activity when combined with $\mathrm{HlgB}(36 \mathrm{kDa})$ [107]. HlgAB is particularly effective at lysing human red blood cells and exhibits cytolytic activity towards human and rabbit leukocytes [104,108,109]. In contrast, HlgCB exhibits limited activity towards red blood cells [56]. The role of HlgACB in S. aureus virulence is not well understood. It is only known that $h \lg A C B$ locus is quite associated with strains able to cause human and bovine colonization, but no association with a particular infection type has been found yet [110-112].

HlgAB was described in 1938 but only in the late 1970s was its biological and biochemical functions assigned due to more reliable purification methods [113,114]. Today, HlgAB has been shown to be required for $S$. aureus survival and proliferation during bloodstream infection, likely through macrophage evasion and nutrient $\left(\mathrm{Fe}^{2+}\right)$ release from erythrocytes $[108,115]$. 
LukED

LukED was initially reported over a decade ago. However, research about this leukotoxin has remained minimal $[105,116]$. LukED has shown its cytolytic activity against rabbit blood cells and leukocytes, but subsequent studies show that this toxin is the only one capable of killing mouse phagocytes with high efficiency $[56,117,118]$. According to epidemiological data, although this toxin is widespread, it is prevalent in epidemic strains [56]. LukED genes have been isolated in $87-93 \%$ of the clinical strains in Japan and 88-99\% in MRSA strains around the world, suggesting the potential contribution of this toxin for $S$. aureus pathogenicity $[98,105,119,120]$.

\section{LukAB/GH}

LukAB (also known as LukGH) is the most recent toxin discovered within the leukotoxin group and the role of this toxin during in vivo infection still remains unclear [121,122]. On the other hand, in vitro studies reported that LukAB/GH targets monocytes, dendritic cells and leukocytes and can cooperate with Panton-Valentine leucocidin (PVL) when co-expressed [110,122,123]. This bi-component leukotoxin is the only one known to enhance $S$. aureus survival as it plays a role in escaping from phagocytes and neutrophils [122,124]. The mechanism under which this toxin promotes survival of S. aureus is likely to be related to its toxicity towards neutrophils, as no hemolytic activity is detectable in the whole blood [122]. Recently, the contribution of LukAB/GH to virulence was demonstrated using a systemic infection model, where the presence of the toxin was associated with higher bacterial burden in infected kidneys [122].

Unlike other leukotoxins, which are secreted as monomers that oligomerize after binding to the cell surface, LukAB/GH heterodimerize before binding its cell-surface receptor. This suggests that LukAB/GH dimerization occurs prior to secretion, as the co-expression of subunits appear to be more toxic than the mixture of individually purified subunits $[125,126]$.

\section{Panton-Valentine Leucocidin (PVL)}

Panton-Valentine Leukocidin (PVL) was firstly purified by Woodin from the culture supernatants of S. aureus V8 [127]. From this purification step, it was possible to separate two protein components of $32 \mathrm{kDa}$ and $38 \mathrm{kDa}$ referred as S, for slow-eluted, and F, for fast-eluted, based on their migration on carboxymethyl cellulose column [127]. All PVL-producing isolates produce the class $S$ and class F proteins specific for PVL (LukS-PV and LukF-PV) and all PVL genes (lukS-PV and lukF-PV) are encoded in several bacteriophages expressing Sa2 integrase [128-130].

The contribution of this leukotoxin in S. aureus virulence is not yet conclusively proven [98]. It is known that PVL is present in a small percentage (approximately $5 \%$ ) in clinical S. aureus strains, but it is strongly associated with community acquired MRSA strains (approximately 85\%), particularly those causing pneumonia, and skin and soft tissue infections [98]. This linkage to virulent strains suggests its capability of causing deadly infections in healthy people [131,132]. A clinical study has shown that pneumonia associated to PVL-positive S. aureus was more lethal compared to PVL-negative [133]. Autopsy of these patients revealed that those with PVL-positive S. aureus had ulcerated and hemorrhagic lungs, suggesting extreme inflammation. In fact, the PVL-induced lysis of macrophages and neutrophils was attributed to the severe inflammation [133,134].

PVL is a cytotoxin that affects leukocytes and causes tissue necrosis and has been associated to furuncles, cutaneous abscesses and severe necrotic skin infections [135-137]. However, the PVL genes were neither detected in strains responsible for endocarditis, mediastinitis, hospital-acquired pneumonia, urinary tract infections and enterocolitis, nor in toxic-shock syndrome [6].

\subsubsection{Phenol-Soluble Modulins}

Phenol-soluble modulins (PSMs) were discovered in 1999 by Mehlin et al. in a S. epidermidis culture [138]. In that study, three peptides were identified-PSM $\alpha, \operatorname{PSM} \beta$ and $\operatorname{PSM} \gamma$-and were 
described as a pro-inflammatory complex isolated by hot phenol extraction from the culture filtrate [138-140]. PSM $\gamma$ is termed also as $\delta$-toxin as it is identical to the S. epidermidis $\delta$-toxin [141].

Studies also led to the identification of PSMs in S. aureus [140]. In S. aureus, PSMs are encoded at three different locations in the genome [140]. PSM $\alpha$ peptides (PSM $\alpha 1-\mathrm{PSM} \alpha 4$ ) are encoded in the psm $\alpha$ operon; PSM $\beta$ (PSM $\beta 1, \operatorname{PSM} \beta 2$ ) are encoded in $\mathrm{psm} \beta$ operon; and $\delta$-toxin is encoded within the coding sequence for RNAIII [142].

PSMs peptides form an $\alpha$-helix amphipathic structure, which stretches over virtually the entire length of the peptide in the shorter $\alpha$-type PSMs, and are located in the carboxy-terminal region in the longer $\beta$-type PSMs. PSMs are believed to attach to the cytoplasmic membrane in a non-specific way, which in turn, can lead to membrane disintegration [50]. It has been considered that phospholipid composition and membrane charge are important for cell susceptibility to PSMs [50].

PSMs differ in their charge characteristics. PSM $\alpha$ are positively charged and PSM $\beta$ are negatively charged, while $\delta$-toxin is neutral [142]. The tendency of PSMs to aggregate in oligomers, forming short-lived pores (Figure 3); and their capacity to facilitate spreading on surfaces or to structure biofilms appears to be the main aspects in pathogenesis [142]. Wang et al. demonstrated that PSM $\alpha$ peptides have a key impact on the ability of community associated MRSA to cause skin infection and bacteraemia; $\delta$-toxin and PSM $\beta$ have little or no effect on the mouse models of $S$. aureus infection [140].

Globally, PSMs peptides in S. aureus have biofilm-structuring activities, indicating their influence on biofilm development via shared physico-chemical properties [53]. Moreover, it is believed that the production of PSMs is highly correlated to the capacity of the staphylococcal species to cause invasive infections, due to their ability to lyse human neutrophils and stimulate inflammatory responses [53,140,143].

(1)

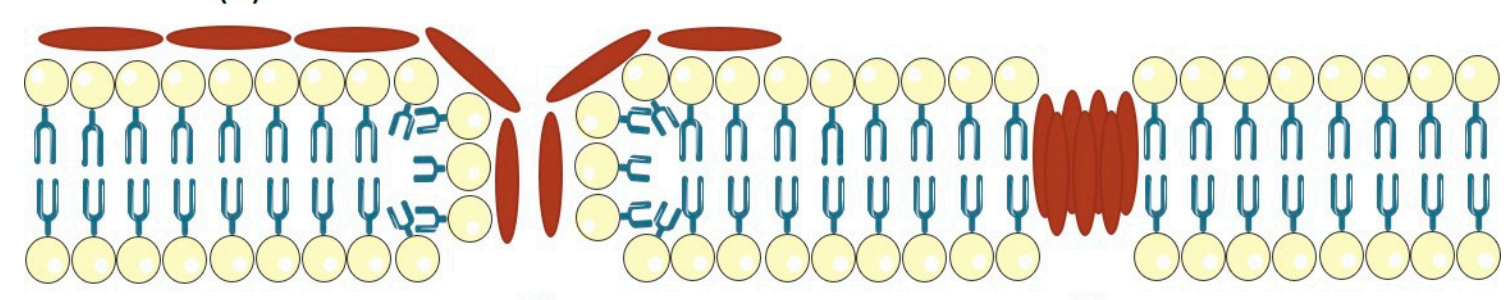

(2)

(3)

Figure 3. Model of pore-formation mechanism for S. aureus PSMs. PSMs attach the cytoplasmic membrane in a non-specific fashion (1), this can lead to membrane disintegration (2). PSMs have the tendency to aggregate in oligomers and form a pore, which is short-lived (3).

\subsection{Exfoliative Toxins (ETs)}

Exfoliative toxins (ETs), also known as epidermolytic toxins, are extremely specific serine proteases secreted by S. aureus. These proteases recognize and hydrolyse desmosome cadherins in the superficial layers of the skin $[144,145]$. ETs are exotoxins associated with the cleavage of keratinocytes junctions and cell-cell adhesion in the epidermis of the host, which can induce skin peeling and blister formation (Figure 4) [146-149].

In 1878, von Rittershain described the clinical features of epidermal exfoliation in newborns [150]. However, the relationship between the exfoliation and S. aureus was only discovered in 1967 by Lyell [151]. The delay between Ritter's and Lyell's discovery was caused by the fact that the blister fluid and exfoliated regions are often free of cultivable staphylococci, because the toxin is distributed from distant sites of infection through the bloodstream [145]. In 1972, Melish et al. discovered the existence of a hypothetical toxin, previously suggested by Lyell, and demonstrated the pathogenic role of those toxins in newborn mice (which were used as experimental models) [152]. 
The principal ETs are known so far are the exfoliative toxin A/B/C/D (ETA, ETB, ETC, ETD). ETA and ETB are the most implicated in human skin damage, while ETC was only isolated from a horse infection and no association with human disease was found [144,153]. ETD was only identified in 2002 in a clinical sample of $S$. aureus [146]. These ETs are produced by approximately 5\% of S. aureus strains, ETA being most prevalent in Europe, Africa and America and ETB more common in Japan [154]. The production of ETs in certain S. aureus strains is related to localized epidermal infections such as bullous impetigo and generalized diseases like SSSS [144].

SSSS is a syndrome characterized by skin exfoliation, but its early manifestations include fever, skin hypersensitivity, and erythema, followed by superficial fluid-filled blister formation and skin separation [145,155-158]. SSSS can affect a large part of the body. However, when a more restricted area is affected, it is categorized as bullous impetigo. Both conditions share the same etiology and only differ in the amount of affected skin [145]. SSSS occurs mainly in infants and children, as they have immature immune systems and weak renal clearance of toxins [12,145]. In general, however, when children are submitted to appropriate treatment, the mortality percentage is quite low (approximately $5 \%)[159,160]$. In contrast, when this syndrome affects adults, especially those with immunosuppressed systems, it has a death rate of approximately 59\% [159].
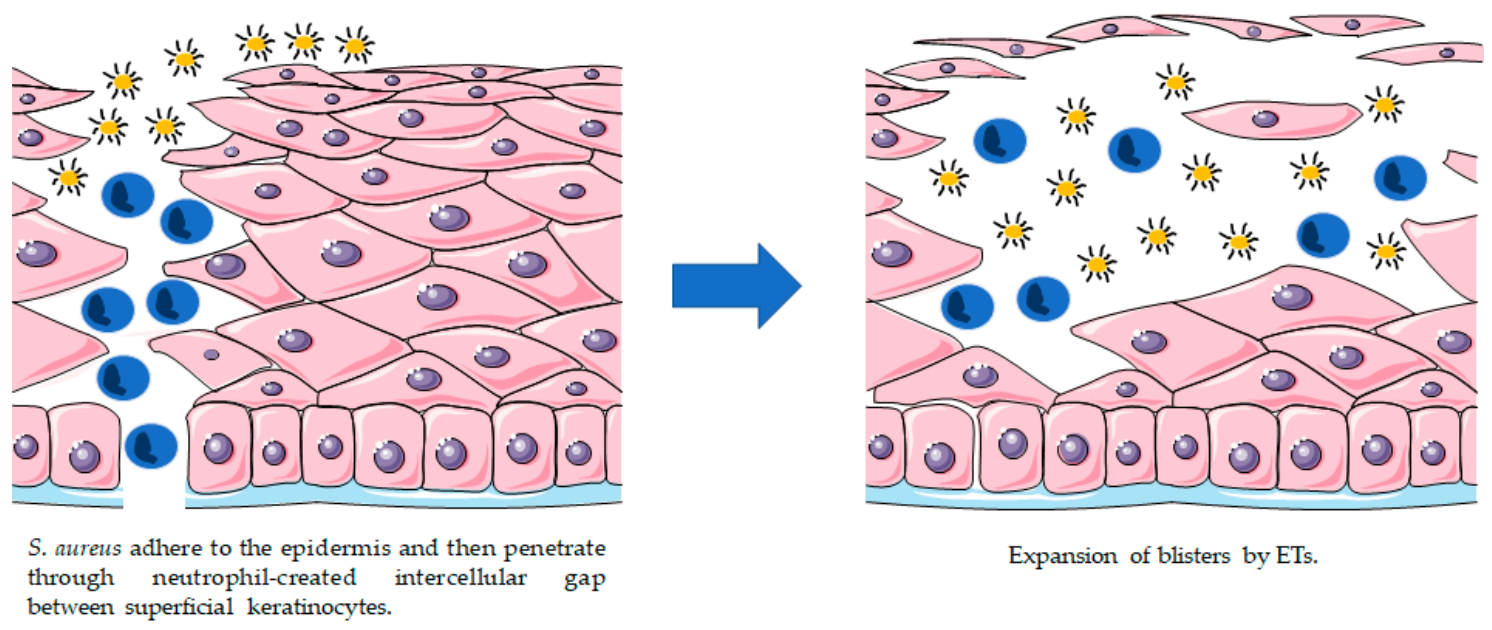

Expansion of blisters by ETs.

Figure 4. Proposed model for bacterial invasion and blistering provoked by staphylococcal ETs.

\subsection{Superantigens (SAgs)}

Originally, Superantigens (SAgs) were termed as staphylococcal enterotoxins (SEs) because they cause symptoms typical of $S$. aureus food poisoning such as vomiting and diarrhea [7]. However, as some of the most recent identified toxins belonging to this group did not present these emetic properties, in 2004, the International Nomenclature Committee gave SE this new nomenclature [7]. There are more than 23 staphylococcal SAgs toxins described, particularly the toxic shock syndrome toxin (TSST-1) and the staphylococcal enterotoxins (SEA to SEE, SEG to SEJ, SEL to SEQ and SER to SET), and 11 staphylococcal superantigen-like (SSL) toxins (SEIK to SEIQ, SEIU to SEIX) [7,9,161-165].

The action mechanism of SAgs was first described by Bernhard Fleischer and Hubert Schrezenmeier in 1988. Since then, it is believed that SAgs activate a large fraction of T lymphocytes simultaneously by directly cross-linking certain $\mathrm{T}$ cell receptor $\mathrm{V} \beta$ domains with conserved structures on major histocompatibility complex class II (MHC II) molecules (Figure 5) [6,161,166,167]. MHC II molecules appear to impact the ability of macrophages to regulate T cell response to SAgs [6]. The released SAgs act systemically, triggering a large number of T-cells to produce massive amounts of pro-inflammatory cytokines (IL-2, IFN- $\gamma$ and TNF), thereby causing the manifestation of symptoms (e.g., high fever, rash, desquamation, vomiting, diarrhea, hypotension, and frequently can result in multiple organ failure) $[168,169]$. After this cytokine storm, a lack of response by T-cells where T-cells 
fail to proliferate or secrete IL-2 is followed, or they can undergo cell death $[170,171]$. This suggests that SAgs are potent immunogens, eliciting and neutralizing antibody response [161,167].

The role of SAgs in some diseases such as sepsis, skin and airway allergies is a matter of discussion [172-176]. For example, from the analysis of patients that suffer from chronic rhinosinusitis, commonly accompanied by intrinsic asthma, it was found that they possess high titres of SAg-specific IgE antibody in the serum or in the polyps, suggesting that SAgs drive or at least amplify chronic airway inflammation $[172,175]$.

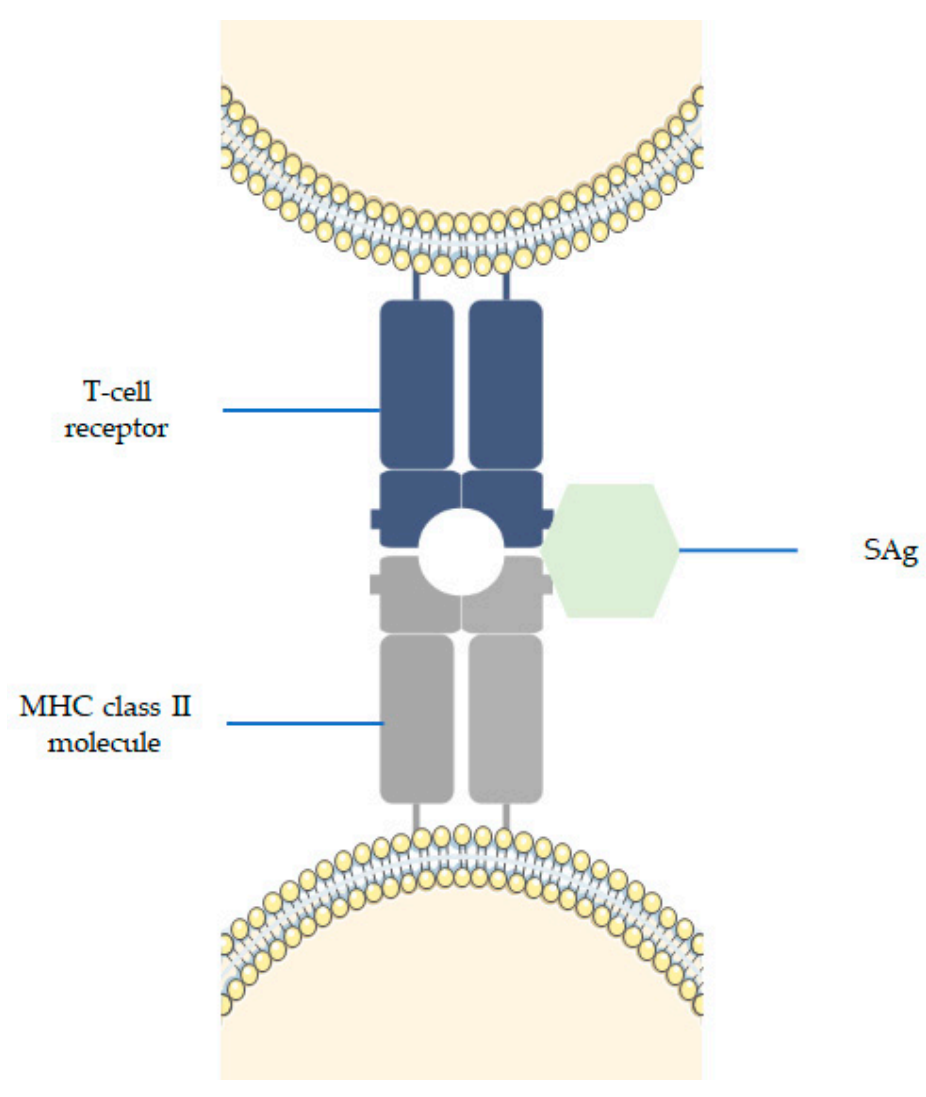

Figure 5. Mechanism of action of SAgs. SAg bind to MHC class II molecules and to a variable region of T-cell receptor, which leads to the stimulation of many T-cells.

\section{Conclusions}

Staphylococci have developed a highly regulated toxin production system that researches are only beginning to understand. However, there is a clear correlation between these toxins and some threatening human diseases. Toxins are attractive key targets for innovative therapeutics. Among the possible strategies, the use of neutralizing antibodies and vaccines are the most promising ones [177-180]. Vaccines against $S$. aureus should induce antibodies to prevent bacterial adherence and allow the neutralization of the toxic exoproteins produced by the bacterium. However, the development of vaccines will be an extraordinary challenge since there is a large number of toxins available and the production of toxins can vary significantly with the staphylococcal genotype. For this reason, a broad spectrum anti-toxin vaccine containing multiple toxins will be needed. Yet, this therapeutic approach should be customized to each patient and adapted to its natural or induced antibody response.

Further research on the pathogenesis of staphylococcal infections will enable the design of a more effective $S$. aureus therapeutic as the strategy of simultaneously using a mixture of inhibitors/antibodies targeting multiple toxins is still incipient. 
Funding: This work was supported by projects: POCI-01-0145-FEDER-030219; POCI-01-0145-FEDER-006939Laboratory for Process Engineering, Environment, Biotechnology and Energy_LEPABE—funded by FEDER funds through COMPETE2020-Programa Operacional Competitividade e Internacionalização (POCI); by national funds through FCT-Fundação para a Ciência e a Tecnologia and the Post-Doc grant awarded to Anabela Borges (SFRH/BPD/98684/2013); and project NORTE-01-0145-FEDER-000005-LEPABE-2-ECO-INNOVATION, funded by FEDER-Fundo Europeu de Desenvolvimento Regional, through COMPETE2020-Programa Operacional Competitividade e Internacionalização (POCI) and Programa Operacional Regional do Norte (NORTE2020).

Conflicts of Interest: The authors declare no conflict of interest. The founding sponsors had no role in the design of the study; in the collection, analyses, or interpretation of data; in the writing of the manuscript, and in the decision to publish the results.

\section{References}

1. Gorwitz, R.J.; Kruszon-Moran, D.; McAllister, S.K.; McQuillan, G.; McDougal, L.K.; Fosheim, G.E.; Jensen, B.J.; Killgore, G.; Tenover, F.C.; Kuehnert, M.J. Changes in the prevalence of nasal colonization with Staphylococcus aureus in the United States, 2001-2004. J. Infect. Dis. 2008, 197, 1226-1234. [CrossRef] [PubMed]

2. Mainous, A.G. Nasal Carriage of Staphylococcus aureus and Methicillin-Resistant S. aureus in the United States, 2001-2002. Ann. Fam. Med. 2006, 4, 132-137. [CrossRef] [PubMed]

3. Tong, S.Y.C.; Davis, J.S.; Eichenberger, E.; Holland, T.L.; Fowler, V.G., Jr. Staphylococcus aureus infections: Epidemiology, pathophysiology, clinical manifestations, and management. Clin. Microbiol. Rev. 2015, 28, 603-661. [CrossRef] [PubMed]

4. Howden, B.P.; Davies, J.K.; Johnson, P.D.R.; Stinear, T.P.; Grayson, M.L. Reduced vancomycin susceptibility in Staphylococcus aureus, including vancomycin-intermediate and heterogeneous vancomycin-intermediate strains: Resistance mechanisms, laboratory detection, and clinical implications. Clin. Microbiol. Rev. 2010, 23, 99-139. [CrossRef] [PubMed]

5. McGuinness, W.A.; Malachowa, N.; DeLeo, F.R. Vancomycin Resistance in Staphylococcus aureus. Yale J. Biol. Med. 2017, 90, 269-281. [PubMed]

6. Honeyman, A.; Friedman, H.; Bendinelli, M. Staphylococcus aureus Infection and Disease; Springer Science \& Business Media: Berlin/Heidelberg, Germany, 2006; ISBN 9780306468483.

7. Grumann, D.; Nübel, U.; Bröker, B.M. Staphylococcus aureus toxins-Their functions and genetics. Infect. Genet. Evol. 2014, 21, 583-592. [CrossRef] [PubMed]

8. Dinges, M.M.; Orwin, P.M.; Schlievert, P.M. Exotoxins of Staphylococcus aureus. Clin. Microbiol. Rev. 2000, 13, 16-34. [CrossRef] [PubMed]

9. Holtfreter, S.; Bröker, B.M. Staphylococcal superantigens: Do they play a role in sepsis? Arch. Immunol. Ther. Exp. 2005, 53, 13-27.

10. Jarraud, S.; Cozon, G.; Vandenesch, F.; Bes, M.; Etienne, J.; Lina, G. Involvement of enterotoxins G and I in staphylococcal toxic shock syndrome and staphylococcal scarlet fever. J. Clin. Microbiol. 1999, 37, 2446-2449. [PubMed]

11. Jarraud, S.; Mougel, C.; Thioulouse, J.; Lina, G.; Meugnier, H.; Forey, F.; Nesme, X.; Etienne, J.; Vandenesch, F. Relationships between Staphylococcus aureus genetic background, virulence factors, agr groups (alleles), and human disease. Infect. Immun. 2002, 70, 631-641. [CrossRef] [PubMed]

12. Ladhani, S. Understanding the mechanism of action of the exfoliative toxins of Staphylococcus aureus. FEMS Immunol. Med. Microbiol. 2003, 39, 181-189. [CrossRef]

13. Otto, M. Basis of virulence in community-associated methicillin-resistant Staphylococcus aureus. Annu. Rev. Microbiol. 2010, 64, 143-162. [CrossRef] [PubMed]

14. Bartlett, A.H.; Hulten, K.G. Staphylococcus aureus pathogenesis: Secretion systems, adhesins, and invasins. Pediatr. Infect. Dis. J. 2010, 29, 860-861. [CrossRef] [PubMed]

15. Shockman, G.D.; Barren, J.F. Structure, Function, and Assembly of Cell Walls of Gram-Positive Bacteria. Annu. Rev. Microbiol. 1983, 37, 501-527. [CrossRef] [PubMed]

16. Lowy, F.D. Staphylococcus aureus infections. N. Engl. J. Med. 1998, 339, 520-532. [CrossRef] [PubMed]

17. Knox, K.W.; Wicken, A.J. Immunological properties of teichoic acids. Bacteriol. Rev. 1973, 37, 215-257. [PubMed]

18. Wilkinson, B.J. The biology of staphylococci. In The Staphylococci in Human Disease; Churchill Livingstone: New York, NY, USA, 1997; pp. 1-38. 
19. Harris, L.G.; Foster, S.J.; Richards, R.G. An introduction to Staphylococcus aureus, and techniques for identifying and quantifying $S$. aureus adhesins in relation to adhesion to biomaterials: Review. Eur. Cells Mater. 2002, 4, 39-60. [CrossRef]

20. Rosenbach, F.J. Mikro-Organismen bei den Wund-Infections-Krankheiten des Menschen; J.F. Bergmann: Wiesbaden, Germany, 1884.

21. Orenstein, A. The Discovery and Naming of Staphylococcus aureus. Available online: http://www. antimicrobe.org/h04c.files/history/S-aureus.pdf (accessed on 8 January 2018).

22. Skinner, D.; Keefer, C.S. Significance of bacteremia caused by Staphylococcus aureus: A study of one hundred and twenty-two cases and a review of the literature concerned with experimental infection in animals. Arch. Intern. Med. 1941, 68, 851-875. [CrossRef]

23. Ladhani, S.; Garbash, M. Staphylococcal Skin Infections in Children. Pediatr. Drugs 2005, 7, 77-102. [CrossRef]

24. Rammelkamp, C.H.; Maxon, T. Resistance of Staphylococcus aureus to the Action of Penicillin. Exp. Biol. Med. 1942, 51, 386-389. [CrossRef]

25. Kirby, W.M. Extraction of a highly potent penicillin inactivator from penicillin resistance staphylococci. Science 1944, 99, 452-453. [CrossRef] [PubMed]

26. Chambers, H. The Changing Epidemiology of Staphylococcus aureus? Emerg. Infect. Dis. 2001, 7, 178-182. [CrossRef] [PubMed]

27. Jevons, M.P. “Celbenin”-Resistant Staphylococci. BMJ 1961, 1, 124-125. [CrossRef]

28. Boyce, J.M.; Causey, W.A. Increasing Occurrence of Methicillin-Resistant Staphylococcus aureus in the United States. Infect. Control 1982, 3, 377-383. [CrossRef] [PubMed]

29. Panlilio, A.L.; Culver, D.H.; Gaynes, R.P.; Banerjee, S.; Henderson, T.S.; Tolson, J.S.; Martone, W.J.; System, N.N.I.S.; National Nosocomial Infections Surveillance System. Methicillin-resistant Staphylococcus aureus in US hospitals, 1975-1991. Infect. Control Hosp. Epidemiol. 1992, 13, 582-586. [CrossRef] [PubMed]

30. Thompson, R.L. Epidemiology of Nosocomial Infections Caused by Methicillin-Resistant Staphylococcus aureus. Ann. Intern. Med. 1982, 97, 309-317. [CrossRef] [PubMed]

31. Boyce, J.M. Methicillin-resistant Staphylococcus aureus. Detection, epidemiology, and control measures. Infect. Dis. Clin. N. Am. 1989, 3, 901-913.

32. Centers for Disease Control and Prevention (CDC). Methicillin-resistant Staphylococcus aureus infections among competitive sports participants-Colorado, Indiana, Pennsylvania, and Los Angeles County, 2000-2003. MMWR Morb. Mortal. Wkly. Rep. 2003, 52, 793-795.

33. Centers for Disease Control and Prevention (CDC). Four pediatric deaths from community-acquired methicillin-resistant Staphylococcus aureus-Minnesota and North Dakota, 1997-1999. MMWR Morb. Mortal. Wkly. Rep. 1999, 48, 707-710.

34. Centers for Disease Control and Prevention (CDC). Methicillin-resistant Staphylococcus aureus skin or soft tissue infections in a state prison-Mississippi, 2000. MMWR Morb. Mortal. Wkly. Rep. 2001, 50, 919-922.

35. Herold, B.C.; Immergluck, L.C.; Maranan, M.C.; Lauderdale, D.S.; Gaskin, R.E.; Boyle-Vavra, S.; Leitch, C.D.; Daum, R.S. Community-acquired methicillin-resistant Staphylococcus aureus in children with no identified predisposing risk. JAMA 1998, 279, 593-598. [CrossRef] [PubMed]

36. Chatterjee, S.S.; Otto, M. Improved understanding of factors driving methicillin-resistant Staphylococcus aureus epidemic waves. Clin. Epidemiol. 2013, 5, 205-217. [PubMed]

37. Millar, B.C.; Loughrey, A.; Elborn, J.S.; Moore, J.E. Proposed definitions of community-associated meticillin-resistant Staphylococcus aureus (CA-MRSA). J. Hosp. Infect. 2007, 67, 109-113. [CrossRef] [PubMed]

38. Penesyan, A.; Gillings, M.; Paulsen, I.T. Antibiotic discovery: Combatting bacterial resistance in cells and in biofilm communities. Molecules 2015, 20, 5286-5298. [CrossRef] [PubMed]

39. Archer, N.K.; Mazaitis, M.J.; Costerton, J.W.; Leid, J.G.; Powers, M.E.; Shirtliff, M.E. Staphylococcus aureus biofilms: Properties, regulation, and roles in human disease. Virulence 2011, 2, 445-459. [CrossRef] [PubMed]

40. Donlan, R.M. Biofilm Formation: A Clinically Relevant Microbiological Process. Clin. Infect. Dis. 2001, 33, 1387-1392. [CrossRef] [PubMed]

41. Beveridge, T.J.; Makin, S.A.; Kadurugamuwa, J.L.; Li, Z. Interactions between biofilms and the environment. FEMS Microbiol. Rev. 1997, 20, 291-303. [CrossRef] [PubMed]

42. Bahna, P.; Dvorak, T.; Hanna, H.; Yasko, A.W.; Hachem, R.; Raad, I. Orthopaedic metal devices coated with a novel antiseptic dye for the prevention of bacterial infections. Int. J. Antimicrob. Agents 2007, 29, 593-596. [CrossRef] [PubMed] 
43. Hussain, M.; Wilcox, M.H.; White, P.J. The slime of coagulase-negative staphylococci: Biochemistry and relation to adherence. FEMS Microbiol. Rev. 1993, 10, 191-207. [CrossRef] [PubMed]

44. Arciola, C.R.; Campoccia, D.; Ravaioli, S.; Montanaro, L. Polysaccharide intercellular adhesin in biofilm: Structural and regulatory aspects. Front. Cell. Infect. Microbiol. 2015, 5, 7. [CrossRef] [PubMed]

45. Mack, D.; Fischer, W.; Krokotsch, A.; Leopold, K.; Hartmann, R.; Egge, H.; Laufs, R. The intercellular adhesin involved in biofilm accumulation of Staphylococcus epidermidis is a linear beta-1,6-linked glucosaminoglycan: Purification and structural analysis. J. Bacteriol. 1996, 178, 175-183. [CrossRef] [PubMed]

46. McDougald, D.; Rice, S.A.; Barraud, N.; Steinberg, P.D.; Kjelleberg, S. Should we stay or should we go: Mechanisms and ecological consequences for biofilm dispersal. Nat. Rev. Microbiol. 2011, 10, 39-50. [CrossRef] [PubMed]

47. Yarwood, J.M.; Bartels, D.J.; Volper, E.M.; Greenberg, E.P. Quorum Sensing in Staphylococcus aureus Biofilms. J. Bacteriol. 2004, 186, 1838-1850. [CrossRef] [PubMed]

48. Boles, B.R.; Horswill, A.R. Agr-mediated dispersal of Staphylococcus aureus biofilms. PLoS Pathog. 2008, 4, e1000052. [CrossRef] [PubMed]

49. Novick, R.P.; Geisinger, E. Quorum Sensing in Staphylococci. Annu. Rev. Genet. 2008, 42, 541-564. [CrossRef] [PubMed]

50. Otto, M. Staphylococcus aureus toxins. Curr. Opin. Microbiol. 2014, 17, 32-37. [CrossRef] [PubMed]

51. Scherr, T.D.; Hanke, M.L.; Huang, O.; James, D.B.A.; Horswill, A.R.; Bayles, K.W.; Fey, P.D.; Torres, V.J.; Kielian, T. Staphylococcus aureus Biofilms Induce Macrophage Dysfunction through Leukocidin AB and Alpha-Toxin. MBio 2015, 6. [CrossRef] [PubMed]

52. Dastgheyb, S.S.; Villaruz, A.E.; Le, K.Y.; Tan, V.Y.; Duong, A.C.; Chatterjee, S.S.; Cheung, G.Y.C.; Joo, H.-S.; Hickok, N.J.; Otto, M. Role of Phenol-Soluble Modulins in Formation of Staphylococcus aureus Biofilms in Synovial Fluid. Infect. Immun. 2015, 83, 2966-2975. [CrossRef] [PubMed]

53. Periasamy, S.; Joo, H.-S.; Duong, A.C.; Bach, T.-H.L.; Tan, V.Y.; Chatterjee, S.S.; Cheung, G.Y.C.; Otto, M. How Staphylococcus aureus biofilms develop their characteristic structure. Proc. Natl. Acad. Sci. USA 2012, 109, 1281-1286. [CrossRef] [PubMed]

54. Song, L.; Hobaugh, M.R.; Shustak, C.; Cheley, S.; Bayley, H.; Gouaux, J.E. Structure of staphylococcal alpha-hemolysin, a heptameric transmembrane pore. Science 1996, 274, 1859-1866. [CrossRef] [PubMed]

55. Gouaux, J.E.; Braha, O.; Hobaugh, M.R.; Song, L.; Cheley, S.; Shustak, C.; Bayley, H. Subunit stoichiometry of staphylococcal alpha-hemolysin in crystals and on membranes: A heptameric transmembrane pore. Proc. Natl. Acad. Sci. USA 1994, 91, 12828-12831. [CrossRef] [PubMed]

56. Seilie, E.S.; Bubeck Wardenburg, J. Staphylococcus aureus pore-forming toxins: The interface of pathogen and host complexity. Semin. Cell Dev. Biol. 2017, 72, 101-116. [CrossRef] [PubMed]

57. Bhakdi, S.; Tranum-Jensen, J. Alpha-toxin of Staphylococcus aureus. Microbiol. Rev. 1991, 55, 733-751. [PubMed]

58. Van der Goot, G. Pore-Forming Toxins; Springer Science \& Business Media: Berlin/Heidelberg, Germany, 2001; Volume 257.

59. Prévost, G.; Mourey, L.; Colin, D.A.; Monteil, H.; Serra, M.D.; Menestrina, G. Alpha-helix and beta-barrel pore-forming toxins (leucocidins, alpha-, gamma-, and delta-cytolysins) of Staphylococcus aureus. In The Comprehensive Sourcebook of Bacterial Protein Toxins; Elsevier: Amsterdam, The Netherlands, 2006; pp. 590-607.

60. Parker, M.W.; Feil, S.C. Pore-forming protein toxins: From structure to function. Prog. Biophys. Mol. Biol. 2005, 88, 91-142. [CrossRef] [PubMed]

61. Bhakdi, S.; Walev, I.; Husmann, M.; Valeva, A. Staphylococcal alpha-toxin. In Topics in Current Genetics; Springer: New York, NY, USA, 2004; pp. 91-110.

62. Powers, M.E.; Kim, H.K.; Wang, Y.; Bubeck Wardenburg, J. ADAM10 mediates vascular injury induced by Staphylococcus aureus $\alpha$-hemolysin. J. Infect. Dis. 2012, 206, 352-356. [CrossRef] [PubMed]

63. Hildebrand, A.; Pohl, M.; Bhakdi, S. Staphylococcus aureus alpha-toxin. Dual mechanism of binding to target cells. J. Biol. Chem. 1991, 266, 17195-17200. [PubMed]

64. Berube, B.J.; Bubeck Wardenburg, J. Staphylococcus aureus $\alpha$-toxin: Nearly a century of intrigue. Toxins 2013, 5, 1140-1166. [CrossRef] [PubMed]

65. Bubeck Wardenburg, J.; Patel, R.J.; Schneewind, O. Surface proteins and exotoxins are required for the pathogenesis of Staphylococcus aureus pneumonia. Infect. Immun. 2007, 75, 1040-1044. [CrossRef] [PubMed] 
66. Nygaard, T.K.; Pallister, K.B.; DuMont, A.L.; DeWald, M.; Watkins, R.L.; Pallister, E.Q.; Malone, C.; Griffith, S.; Horswill, A.R.; Torres, V.J.; et al. Alpha-Toxin Induces Programmed Cell Death of Human T cells, B cells, and Monocytes during USA300 Infection. PLoS ONE 2012, 7, e36532. [CrossRef] [PubMed]

67. Manohar, M.; Maheswaran, S.K.; Frommes, S.P.; Lindorfer, R.K. Platelet damaging factor, a fifth activity of staphylococcal alpha-toxin. J. Bacteriol. 1967, 94, 224-231. [PubMed]

68. Bhakdi, S.; Muhly, M.; Mannhardt, U.; Hugo, F.; Klapettek, K.; Mueller-Eckhardt, C.; Roka, L. Staphylococcal alpha toxin promotes blood coagulation via attack on human platelets. J. Exp. Med. 1988, 168, 527-542. [CrossRef] [PubMed]

69. Cassidy, P.; Harshman, S. Studies on the binding of staphylococcal 125I-labeled $\alpha$-toxin to rabbit erythrocytes. Biochemistry 1976, 15, 2348-2355. [CrossRef] [PubMed]

70. Lizak, M.; Yarovinsky, T.O. Phospholipid scramblase 1 mediates type I interferon-induced protection against staphylococcal $\alpha$-toxin. Cell Host Microbe 2012, 11, 70-80. [CrossRef] [PubMed]

71. Bhakdi, S.; Muhly, M.; Korom, S.; Hugo, F. Release of interleukin-1 beta associated with potent cytocidal action of staphylococcal alpha-toxin on human monocytes. Infect. Immun. 1989, 57, 3512-3519. [PubMed]

72. Grimminger, F.; Rose, F.; Sibelius, U.; Meinhardt, M.; Pötzsch, B.; Spriestersbach, R.; Bhakdi, S.; Suttorp, N.; Seeger, W. Human endothelial cell activation and mediator release in response to the bacterial exotoxins Escherichia coli hemolysin and staphylococcal alpha-toxin. J. Immunol. 1997, 159, 1909-1916. [PubMed]

73. Suttorp, N.; Seeger, W.; Dewein, E.; Bhakdi, S.; Roka, L. Staphylococcal alpha-toxin-induced PGI2 production in endothelial cells: Role of calcium. Am. J. Physiol. Cell Physiol. 1985, 248, C127-C134. [CrossRef] [PubMed]

74. Rose, F.; Dahlem, G.; Guthmann, B.; Grimminger, F.; Maus, U.; Hänze, J.; Duemmer, N.; Grandel, U.; Seeger, W.; Ghofrani, H.A. Mediator generation and signaling events in alveolar epithelial cells attacked by S. aureus $\alpha$-toxin. Am. J. Physiol. Lung Cell. Mol. Physiol. 2002, 282, L207-L214. [CrossRef] [PubMed]

75. Suttorp, N.; Fuhrmann, M.; Tannert-Otto, S.; Grimminger, F.; Bhadki, S. Pore-forming bacterial toxins potently induce release of nitric oxide in porcine endothelial cells. J. Exp. Med. 1993, 178, 337-341. [CrossRef] [PubMed]

76. Maretzky, T.; Scholz, F.; Köten, B.; Proksch, E.; Saftig, P.; Reiss, K. ADAM10-mediated E-cadherin release is regulated by proinflammatory cytokines and modulates keratinocyte cohesion in eczematous dermatitis. J. Investig. Dermatol. 2008, 128, 1737-1746. [CrossRef] [PubMed]

77. Maretzky, T.; Reiss, K.; Ludwig, A.; Buchholz, J.; Scholz, F.; Proksch, E.; de Strooper, B.; Hartmann, D.; Saftig, P. ADAM10 mediates E-cadherin shedding and regulates epithelial cell-cell adhesion, migration, and beta-catenin translocation. Proc. Natl. Acad. Sci. USA 2005, 102, 9182-9187. [CrossRef] [PubMed]

78. Seals, D.F.; Courtneidge, S.A. The ADAMs family of metalloproteases: Multidomain proteins with multiple functions. Genes Dev. 2003, 17, 7-30. [CrossRef] [PubMed]

79. Edwards, D.; Handsley, M.; Pennington, C. The ADAM metalloproteinases. Mol. Asp. Med. 2008, 29, $258-289$. [CrossRef] [PubMed]

80. Inoshima, I.; Inoshima, N.; Wilke, G.A.; Powers, M.E.; Frank, K.M.; Wang, Y.; Bubeck Wardenburg, J. A Staphylococcus aureus pore-forming toxin subverts the activity of ADAM10 to cause lethal infection in mice. Nat. Med. 2011, 17, 1310-1314. [CrossRef] [PubMed]

81. Kolata, J.; Bode, L.G.M.; Holtfreter, S.; Steil, L.; Kusch, H.; Holtfreter, B.; Albrecht, D.; Hecker, M.; Engelmann, S.; van Belkum, A.; et al. Distinctive patterns in the human antibody response to Staphylococcus aureus bacteremia in carriers and non-carriers. Proteomics 2011, 11, 3914-3927. [CrossRef] [PubMed]

82. Fritz, S.A.; Tiemann, K.M.; Hogan, P.G.; Epplin, E.K.; Rodriguez, M.; Al-Zubeidi, D.N.; Bubeck Wardenburg, J.; Hunstad, D.A. A serologic correlate of protective immunity against community-onset Staphylococcus aureus infection. Clin. Infect. Dis. 2013, 56, 1554-1561. [CrossRef] [PubMed]

83. Adhikari, R.P.; Ajao, A.O.; Aman, M.J.; Karauzum, H.; Sarwar, J.; Lydecker, A.D.; Johnson, J.K.; Nguyen, C.; Chen, W.H.; Roghmann, M.-C. Lower antibody levels to Staphylococcus aureus exotoxins are associated with sepsis in hospitalized adults with invasive S. aureus infections. J. Infect. Dis. 2012, 206, 915-923. [CrossRef] [PubMed]

84. DeLeo, F.R.; Kennedy, A.D.; Chen, L.; Bubeck Wardenburg, J.; Kobayashi, S.D.; Mathema, B.; Braughton, K.R.; Whitney, A.R.; Villaruz, A.E.; Martens, C.A.; et al. Molecular differentiation of historic phage-type 80/81 and contemporary epidemic Staphylococcus aureus. Proc. Natl. Acad. Sci. USA 2011, 108, 18091-18096. [CrossRef] [PubMed]

85. Glenny, A.T.; Stevens, M.F. Staphylococcus toxins and antitoxins. J. Pathol. 1935, 40, 201-210. [CrossRef] 
86. Projan, S.J.; Kornblum, J.; Kreiswirth, B.; Moghazeh, S.L.; Eisner, W.; Novick, R.P. Nucleotide sequence: The beta-hemolysin gene of Staphylococcus aureus. Nucleic Acids Res. 1989, 17, 3305. [CrossRef] [PubMed]

87. Doery, H.M.; Magnusson, B.J.; Gulasekharam, J.; Pearson, J.E. The properties of phospholipase enzymes in staphylococcal toxins. J. Gen. Microbiol. 1965, 40, 283-296. [CrossRef] [PubMed]

88. Flores-Díaz, M.; Monturiol-Gross, L.; Naylor, C.; Alape-Girón, A.; Flieger, A. Bacterial Sphingomyelinases and Phospholipases as Virulence Factors. Microbiol. Mol. Biol. Rev. 2016, 80, 597-628. [CrossRef] [PubMed]

89. Aarestrup, F.M.; Larsen, H.D.; Eriksen, N.; Elsberg, C.S.; Jensen, N.E. Frequency of $\alpha$-and $\beta$-haemolysin in Staphylococcus aureus of bovine and human origin. APMIS 1999, 107, 425-430. [CrossRef] [PubMed]

90. Katayama, Y.; Baba, T.; Sekine, M.; Fukuda, M.; Hiramatsu, K. Beta-hemolysin promotes skin colonization by Staphylococcus aureus. J. Bacteriol. 2013, 195, 1194-1203. [CrossRef] [PubMed]

91. Tajima, A.; Iwase, T.; Shinji, H.; Seki, K.; Mizunoe, Y. Inhibition of endothelial interleukin-8 production and neutrophil transmigration by Staphylococcus aureus beta-hemolysin. Infect. Immun. 2009, 77, 327-334. [CrossRef] [PubMed]

92. Huseby, M.J.; Kruse, A.C.; Digre, J.; Kohler, P.L.; Vocke, J.A.; Mann, E.E.; Bayles, K.W.; Bohach, G.A.; Schlievert, P.M.; Ohlendorf, D.H.; et al. Beta toxin catalyzes formation of nucleoprotein matrix in staphylococcal biofilms. Proc. Natl. Acad. Sci. USA 2010, 107, 14407-14412. [CrossRef] [PubMed]

93. Huseby, M.; Shi, K.; Brown, C.K.; Digre, J.; Mengistu, F.; Seo, K.S.; Bohach, G.A.; Schlievert, P.M.; Ohlendorf, D.H.; Earhart, C.A. Structure and biological activities of beta toxin from Staphylococcus aureus. J. Bacteriol. 2007, 189, 8719-8726. [CrossRef] [PubMed]

94. Walev, I.; Weller, U.; Strauch, S.; Foster, T.; Bhakdi, S. Selective killing of human monocytes and cytokine release provoked by sphingomyelinase (beta-toxin) of Staphylococcus aureus. Infect. Immun. 1996, 64, 2974-2979. [PubMed]

95. Hayashida, A.; Bartlett, A.H.; Foster, T.J.; Park, P.W. Staphylococcus aureus beta-toxin induces lung injury through syndecan-1. Am. J. Pathol. 2009, 174, 509-518. [CrossRef] [PubMed]

96. Yamashita, K.; Kawai, Y.; Tanaka, Y.; Hirano, N.; Kaneko, J.; Tomita, N.; Ohta, M.; Kamio, Y.; Yao, M.; Tanaka, I. Crystal structure of the octameric pore of staphylococcal $\gamma$-Hemolysin reveals the $\beta$-Barrel pore formation mechanism by two components. Proc. Natl. Acad. Sci. USA 2011, 108, 17314-17319. [CrossRef] [PubMed]

97. Aman, M.J.; Karauzum, H.; Bowden, M.G.; Nguyen, T.L. Structural model of the pre-pore ring-like structure of Panton-Valentine leukocidin: Providing dimensionality to biophysical and mutational data. J. Biomol. Struct. Dyn. 2010, 28, 1-12. [CrossRef] [PubMed]

98. Yoong, P.; Torres, V.J. The effects of Staphylococcus aureus leukotoxins on the host: Cell lysis and beyond. Curr. Opin. Microbiol. 2013, 16, 63-69. [CrossRef] [PubMed]

99. Spaan, A.N.; Schiepers, A.; de Haas, C.J.C.; van Hooijdonk, D.D.J.J.; Badiou, C.; Contamin, H.; Vandenesch, F.; Lina, G.; Gerard, N.P.; Gerard, C.; et al. Differential Interaction of the Staphylococcal Toxins Panton-Valentine Leukocidin and $\gamma$-Hemolysin CB with Human C5a Receptors. J. Immunol. 2015, 195, 1034-1043. [CrossRef] [PubMed]

100. Kaneko, J.; Ozawa, T.; Tomita, T.; Kamio, Y. Sequential Binding of Staphylococcal $\gamma$-Hemolysin to Human Erythrocytes and Complex Formation of the Hemolysin on the Cell Surface. Biosci. Biotechnol. Biochem. 1997, 61, 846-851. [CrossRef] [PubMed]

101. Miles, G.; Movileanu, L.; Bayley, H. Subunit composition of a bicomponent toxin: Staphylococcal leukocidin forms an octameric transmembrane pore. Protein Sci. 2002, 11, 894-902. [CrossRef] [PubMed]

102. Sugawara-Tomita, N.; Tomita, T.; Kamio, Y. Stochastic assembly of two-component staphylococcal gamma-hemolysin into heteroheptameric transmembrane pores with alternate subunit arrangements in ratios of 3:4 and 4:3. J. Bacteriol. 2002, 184, 4747-4756. [CrossRef] [PubMed]

103. Jayasinghe, L.; Bayley, H. The leukocidin pore: Evidence for an octamer with four LukF subunits and four LukS subunits alternating around a central axis. Protein Sci. 2005, 14, 2550-2561. [CrossRef] [PubMed]

104. Prévost, G.; Cribier, B.; Couppié, P.; Petiau, P.; Supersac, G.; Finck-Barbançon, V.; Monteil, H.; Piemont, Y. Panton-Valentine leucocidin and gamma-hemolysin from Staphylococcus aureus ATCC 49775 are encoded by distinct genetic loci and have different biological activities. Infect. Immun. 1995, 63, 4121-4129. [PubMed]

105. Morinaga, N.; Kaihou, Y.; Noda, M. Purification, cloning and characterization of variant LukE-LukD with strong leukocidal activity of staphylococcal bi-component leukotoxin family. Microbiol. Immunol. 2003, 47, 81-90. [CrossRef] [PubMed] 
106. Kamio, Y.; Rahman, A.; Nariya, H.; Ozawa, T.; Izaki, K. The two Staphylococcal bi-component toxins, leukocidin and gamma-hemolysin, share one component in common. FEBS Lett. 1993, 321, 15-18. [CrossRef]

107. Cooney, J.; Kienle, Z.; Foster, T.J.; O'Toole, P.W. The gamma-hemolysin locus of Staphylococcus aureus comprises three linked genes, two of which are identical to the genes for the $\mathrm{F}$ and $\mathrm{S}$ components of leukocidin. Infect. Immun. 1993, 61, 768-771. [PubMed]

108. Spaan, A.N.; Reyes-Robles, T.; Badiou, C.; Cochet, S.; Boguslawski, K.M.; Yoong, P.; Day, C.J.; de Haas, C.J.C.; van Kessel, K.P.M.; Vandenesch, F.; et al. Staphylococcus aureus Targets the Duffy Antigen Receptor for Chemokines (DARC) to Lyse Erythrocytes. Cell Host Microbe 2015, 18, 363-370. [CrossRef] [PubMed]

109. Fackrell, H.B.; Wiseman, G.M. Properties of the gamma haemolysin of Staphylococcus aureus "Smith $5 R^{\text {". }}$ J. Gen. Microbiol. 1976, 92, 11-24. [CrossRef] [PubMed]

110. Shukla, S.K.; Karow, M.E.; Brady, J.M.; Stemper, M.E.; Kislow, J.; Moore, N.; Wroblewski, K.; Chyou, P.-H.; Warshauer, D.M.; Reed, K.D.; et al. Virulence genes and genotypic associations in nasal carriage, community-associated methicillin-susceptible and methicillin-resistant USA400 Staphylococcus aureus isolates. J. Clin. Microbiol. 2010, 48, 3582-3592. [CrossRef] [PubMed]

111. Peacock, S.J.; Moore, C.E.; Justice, A.; Kantzanou, M.; Story, L.; Mackie, K.; O’Neill, G.; Day, N.P.J. Virulent combinations of adhesin and toxin genes in natural populations of Staphylococcus aureus. Infect. Immun. 2002, 70, 4987-4996. [CrossRef] [PubMed]

112. Fueyo, J.M.; Mendoza, M.C.; Rodicio, M.R.; Muñiz, J.; Alvarez, M.A.; Martín, M.C. Cytotoxin and pyrogenic toxin superantigen gene profiles of Staphylococcus aureus associated with subclinical mastitis in dairy cows and relationships with macrorestriction genomic profiles. J. Clin. Microbiol. 2005, 43, 1278-1284. [CrossRef] [PubMed]

113. Smith, M.L.; Llewellyn Smith, M.; Price, S.A. Staphylococcus $\gamma$ haemolysin. J. Pathol. Bacteriol. 1938, 47, 379-393. [CrossRef]

114. Guyonnet, F.; Plommet, M. Staphyloccal gama lysin. Purification and Properties. Ann. Inst. Pasteur 1970, 118, 19-33.

115. Spaan, A.N.; Vrieling, M.; Wallet, P.; Badiou, C.; Reyes-Robles, T.; Ohneck, E.A.; Benito, Y.; de Haas, C.J.C.; Day, C.J.; Jennings, M.P.; et al. The staphylococcal toxins $\gamma$-haemolysin AB and CB differentially target phagocytes by employing specific chemokine receptors. Nat. Commun. 2014, 5, 5438. [CrossRef] [PubMed]

116. Gravet, A.; Colin, D.A.; Keller, D.; Girardot, R.; Monteil, H.; Prévost, G.; Giradot, R. Characterization of a novel structural member, LukE-LukD, of the bi-component staphylococcal leucotoxins family. FEBS Lett. 1998, 436, 202-208. [CrossRef]

117. Alonzo, F., 3rd; Benson, M.A.; Chen, J.; Novick, R.P.; Shopsin, B.; Torres, V.J. Staphylococcus aureus leucocidin ED contributes to systemic infection by targeting neutrophils and promoting bacterial growth in vivo. Mol. Microbiol. 2012, 83, 423-435. [CrossRef] [PubMed]

118. Alonzo, F., 3rd; Kozhaya, L.; Rawlings, S.A.; Reyes-Robles, T.; DuMont, A.L.; Myszka, D.G.; Landau, N.R.; Unutmaz, D.; Torres, V.J. CCR5 is a receptor for Staphylococcus aureus leukotoxin ED. Nature 2013, 493, 51-55. [CrossRef] [PubMed]

119. Liu, C.; Chen, Z.-J.; Sun, Z.; Feng, X.; Zou, M.; Cao, W.; Wang, S.; Zeng, J.; Wang, Y.; Sun, M. Molecular characteristics and virulence factors in methicillin-susceptible, resistant, and heterogeneous vancomycin-intermediate Staphylococcus aureus from central-southern China. J. Microbiol. Immunol. Infect. 2015, 48, 490-496. [CrossRef] [PubMed]

120. Vandenesch, F.; Naimi, T.; Enright, M.C.; Lina, G.; Nimmo, G.R.; Heffernan, H.; Liassine, N.; Bes, M.; Greenland, T.; Reverdy, M.-E.; et al. Community-acquired methicillin-resistant Staphylococcus aureus carrying Panton-Valentine leukocidin genes: Worldwide emergence. Emerg. Infect. Dis. 2003, 9, 978-984. [CrossRef] [PubMed]

121. Ventura, C.L.; Malachowa, N.; Hammer, C.H.; Nardone, G.A.; Robinson, M.A.; Kobayashi, S.D.; DeLeo, F.R. Identification of a novel Staphylococcus aureus two-component leukotoxin using cell surface proteomics. PLoS ONE 2010, 5, e11634. [CrossRef] [PubMed]

122. Dumont, A.L.; Nygaard, T.K.; Watkins, R.L.; Smith, A.; Kozhaya, L.; Kreiswirth, B.N.; Shopsin, B.; Unutmaz, D.; Voyich, J.M.; Torres, V.J. Characterization of a new cytotoxin that contributes to Staphylococcus aureus pathogenesis. Mol. Microbiol. 2011, 79, 814-825. [CrossRef] [PubMed] 
123. Melehani, J.H.; James, D.B.A.; DuMont, A.L.; Torres, V.J.; Duncan, J.A. Staphylococcus aureus Leukocidin A/B (LukAB) Kills Human Monocytes via Host NLRP3 and ASC when Extracellular, but Not Intracellular. PLoS Pathog. 2015, 11, e1004970. [CrossRef] [PubMed]

124. DuMont, A.L.; Yoong, P.; Surewaard, B.G.J.; Benson, M.A.; Nijland, R.; van Strijp, J.A.G.; Torres, V.J. Staphylococcus aureus elaborates leukocidin $\mathrm{AB}$ to mediate escape from within human neutrophils. Infect. Immun. 2013, 81, 1830-1841. [CrossRef] [PubMed]

125. DuMont, A.L.; Yoong, P.; Liu, X.; Day, C.J.; Chumbler, N.M.; James, D.B.A.; Alonzo, F., 3rd; Bode, N.J.; Lacy, D.B.; Jennings, M.P.; et al. Identification of a crucial residue required for Staphylococcus aureus LukAB cytotoxicity and receptor recognition. Infect. Immun. 2014, 82, 1268-1276. [CrossRef] [PubMed]

126. Badarau, A.; Rouha, H.; Malafa, S.; Logan, D.T.; Håkansson, M.; Stulik, L.; Dolezilkova, I.; Teubenbacher, A.; Gross, K.; Maierhofer, B.; et al. Structure-function analysis of heterodimer formation, oligomerization, and receptor binding of the Staphylococcus aureus bi-component toxin LukGH. J. Biol. Chem. 2015, 290, 142-156. [CrossRef] [PubMed]

127. Woodin, A.M. Purification of the two components of leucocidin from Staphylococcus aureus. Biochem. J. 1960, 75, 158-165. [CrossRef] [PubMed]

128. Kaneko, J.; Kimura, T.; Narita, S.; Tomita, T.; Kamio, Y. Complete nucleotide sequence and molecular characterization of the temperate staphylococcal bacteriophage $\varphi$ PVL carrying Panton-Valentine leukocidin genes. Gene 1998, 215, 57-67. [CrossRef]

129. Kaneko, J.; Kimura, T.; Kawakami, Y.; Tomita, T.; Kamio, Y. Panton-Valentíne Leukocidin Genes in a Phage-like Particle Isolated from Mitomycin C-Treated Staphylococcus aureus V8 (ATCC 49775). Biosci. Biotechnol. Biochem. 1997, 61, 1960-1962. [CrossRef] [PubMed]

130. Goerke, C.; Pantucek, R.; Holtfreter, S.; Schulte, B.; Zink, M.; Grumann, D.; Bröker, B.M.; Doskar, J.; Wolz, C. Diversity of prophages in dominant Staphylococcus aureus clonal lineages. J. Bacteriol. 2009, 191, 3462-3468. [CrossRef] [PubMed]

131. Lina, G.; Piémont, Y.; Godail-Gamot, F.; Bes, M.; Peter, M.O.; Gauduchon, V.; Vandenesch, F.; Etienne, J. Involvement of Panton-Valentine leukocidin-producing Staphylococcus aureus in primary skin infections and pneumonia. Clin. Infect. Dis. 1999, 29, 1128-1132. [CrossRef] [PubMed]

132. Naimi, T.S. Comparison of Community- and Health Care-Associated Methicillin-Resistant Staphylococcus aureus Infection. JAMA 2003, 290, 2976-2984. [CrossRef] [PubMed]

133. Gillet, Y.; Issartel, B.; Vanhems, P.; Fournet, J.-C.; Lina, G.; Bes, M.; Vandenesch, F.; Piémont, Y.; Brousse, N.; Floret, D.; et al. Association between Staphylococcus aureus strains carrying gene for Panton-Valentine leukocidin and highly lethal necrotising pneumonia in young immunocompetent patients. Lancet 2002, 359, 753-759. [CrossRef]

134. Finck-Barbançon, V.; Duportail, G.; Meunier, O.; Colin, D.A. Pore formation by a two-component leukocidin from Staphylococcus aureus within the membrane of human polymorphonuclear leukocytes. Biochim. Biophys. Acta 1993, 1182, 275-282. [CrossRef]

135. Cribier, B. Leukocidin from Staphylococcus aureus and Cutaneous Infections: An Epidemiologic Study. Arch. Dermatol. 1994, 130, 1208-1209. [CrossRef]

136. Cribier, B.; Prévost, G.; Couppie, P.; Finck-Barbançon, V.; Grosshans, E.; Piémont, Y. Staphylococcus aureus leukocidin: A new virulence factor in cutaneous infections? An epidemiological and experimental study. Dermatology 1992, 185, 175-180. [CrossRef] [PubMed]

137. Prevost, G.; Couppie, P.; Prevost, P.; Gayet, S.; Petiau, P.; Cribier, B.; Monteil, H.; Piemont, Y. Epidemiological data on Staphylococcus aureus strains producing synergohymenotropic toxins. J. Med. Microbiol. 1995, 42, 237-245. [CrossRef] [PubMed]

138. Mehlin, C.; Headley, C.M.; Klebanoff, S.J. An inflammatory polypeptide complex from Staphylococcus epidermidis: Isolation and characterization. J. Exp. Med. 1999, 189, 907-918. [CrossRef] [PubMed]

139. Yoshida, A. Staphylococcal delta-hemolysin. I. Purification and chemical properties. Biochim. Biophys. Acta 1963, 71, 544-553. [CrossRef]

140. Wang, R.; Braughton, K.R.; Kretschmer, D.; Bach, T.-H.L.; Queck, S.Y.; Li, M.; Kennedy, A.D.; Dorward, D.W.; Klebanoff, S.J.; Peschel, A.; et al. Identification of novel cytolytic peptides as key virulence determinants for community-associated MRSA. Nat. Med. 2007, 13, 1510-1514. [CrossRef] [PubMed]

141. McKevitt, A.I.; Bjornson, G.L.; Mauracher, C.A.; Scheifele, D.W. Amino acid sequence of a deltalike toxin from Staphylococcus epidermidis. Infect. Immun. 1990, 58, 1473-1475. [PubMed] 
142. Peschel, A.; Otto, M. Phenol-soluble modulins and staphylococcal infection. Nat. Rev. Microbiol. 2013, 11, 667-673. [CrossRef] [PubMed]

143. Rautenberg, M.; Joo, H.-S.; Otto, M.; Peschel, A. Neutrophil responses to staphylococcal pathogens and commensals via the formyl peptide receptor 2 relates to phenol-soluble modulin release and virulence. FASEB J. 2011, 25, 1254-1263. [CrossRef] [PubMed]

144. Mariutti, R.B.; Tartaglia, N.R.; Seyffert, N.; de Paula Castro, T.L.; Arni, R.K.; Azevedo, V.A.; Le Loir, Y.; Nishifuji, K. Exfoliative Toxins of Staphylococcus aureus. In The Rise of Virulence and Antibiotic Resistance in Staphylococcus aureus; IntechOpen: London, UK, 2017.

145. Bukowski, M.; Wladyka, B.; Dubin, G. Exfoliative Toxins of Staphylococcus aureus. Toxins 2010, 2, 1148-1165. [CrossRef] [PubMed]

146. Nishifuji, K.; Sugai, M.; Amagai, M. Staphylococcal exfoliative toxins: "molecular scissors" of bacteria that attack the cutaneous defense barrier in mammals. J. Dermatol. Sci. 2008, 49, 21-31. [CrossRef] [PubMed]

147. Amagai, M.; Yamaguchi, T.; Hanakawa, Y.; Nishifuji, K.; Sugai, M.; Stanley, J.R. Staphylococcal exfoliative toxin B specifically cleaves desmoglein 1. J. Investig. Dermatol. 2002, 118, 845-850. [CrossRef] [PubMed]

148. Melish, M.E.; Glasgow, L.A. Staphylococcal scalded skin syndrome: The expanded clinical syndrome. J. Pediatr. 1971, 78, 958-967. [CrossRef]

149. Yamaguchi, T.; Nishifuji, K.; Sasaki, M.; Fudaba, Y.; Aepfelbacher, M.; Takata, T.; Ohara, M.; Komatsuzawa, H.; Amagai, M.; Sugai, M. Identification of the Staphylococcus aureus etd pathogenicity island which encodes a novel exfoliative toxin, ETD, and EDIN-B. Infect. Immun. 2002, 70, 5835-5845. [CrossRef] [PubMed]

150. Ritter von Rittershain, B.G. Die Exfoliative Dermatities Jungener Senglinge. Z. Kinderheilkd. 1878, 2, 3-23.

151. Lyell, A. A review of toxic epidermal necrolysis in Britain. Br. J. Dermatol. 1967, 79, 662-671. [CrossRef] [PubMed]

152. Melish, M.E.; Glasgow, L.A.; Turner, M.D. The staphylococcal scalded-skin syndrome: Isolation and partial characterization of the exfoliative toxin. J. Infect. Dis. 1972, 125, 129-140. [CrossRef] [PubMed]

153. Lee, C.Y.; Schmidt, J.J.; Johnson-Winegar, A.D.; Spero, L.; Iandolo, J.J. Sequence determination and comparison of the exfoliative toxin A and toxin B genes from Staphylococcus aureus. J. Bacteriol. 1987, 169, 3904-3909. [CrossRef] [PubMed]

154. Ladhani, S. Recent developments in staphylococcal scalded skin syndrome. Clin. Microbiol. Infect. 2001, 7, 301-307. [CrossRef] [PubMed]

155. Cribier, B.; Piemont, Y.; Grosshans, E. Staphylococcal scalded skin syndrome in adults. A clinical review illustrated with a new case. J. Am. Acad. Dermatol. 1994, 30, 319-324. [CrossRef]

156. Hardwick, N.; Parry, C.M.; Sharpe, G.R. Staphylococcal scalded skin syndrome in an adult. Influence of immune and renal factors. Br. J. Dermatol. 1995, 132, 468-471. [CrossRef] [PubMed]

157. Sakurai, S.; Suzuki, H.; Machida, K. Rapid Identification by Polymerase Chain Reaction of Staphylococcal Exfoliative Toxin Serotype A and B Genes. Microbiol. Immunol. 1995, 39, 379-386. [CrossRef] [PubMed]

158. Wiley, B.B.; Rogolsky, M. Molecular and serological differentiation of staphylococcal exfoliative toxin synthesized under chromosomal and plasmid control. Infect. Immun. 1977, 18, 487-494. [PubMed]

159. Popov, L.; Kovalski, J.; Grandi, G.; Bagnoli, F.; Amieva, M.R. Three-Dimensional Human Skin Models to Understand Staphylococcus aureus Skin Colonization and Infection. Front. Immunol. 2014, 5, 41. [CrossRef] [PubMed]

160. Lyell, A. Toxic epidermal necrolysis (the scalded skin syndrome): A reappraisal. Br. J. Dermatol. 1979, 100, 69-86. [CrossRef] [PubMed]

161. Grumann, D.; Ruotsalainen, E.; Kolata, J.; Kuusela, P.; Järvinen, A.; Kontinen, V.P.; Bröker, B.M.; Holtfreter, S. Characterization of infecting strains and superantigen-neutralizing antibodies in Staphylococcus aureus bacteremia. Clin. Vaccine Immunol. 2011, 18, 487-493. [CrossRef] [PubMed]

162. Lina, G.; Bohach, G.A.; Nair, S.P.; Hiramatsu, K.; Jouvin-Marche, E.; Mariuzza, R. Standard nomenclature for the superantigens expressed by Staphylococcus. J. Infect. Dis. 2004, 189, 2334-2336. [CrossRef] [PubMed]

163. Ono, H.K.; Omoe, K.; Imanishi, K.; Iwakabe, Y.; Hu, D.-L.; Kato, H.; Saito, N.; Nakane, A.; Uchiyama, T.; Shinagawa, K. Identification and Characterization of Two Novel Staphylococcal Enterotoxins, Types S and T. Infect. Immun. 2008, 76, 4999-5005. [CrossRef] [PubMed]

164. Proft, T.; Fraser, J.D. Bacterial superantigens. Clin. Exp. Immunol. 2003, 133, 299-306. [CrossRef] [PubMed] 
165. Wilson, G.J.; Seo, K.S.; Cartwright, R.A.; Connelley, T.; Chuang-Smith, O.N.; Merriman, J.A.; Guinane, C.M.; Park, J.Y.; Bohach, G.A.; Schlievert, P.M.; et al. A novel core genome-encoded superantigen contributes to lethality of community-associated MRSA necrotizing pneumonia. PLoS Pathog. 2011, 7, e1002271. [CrossRef] [PubMed]

166. Fleischer, B. T cell stimulation by staphylococcal enterotoxins. Clonally variable response and requirement for major histocompatibility complex class II molecules on accessory or target cells. J. Exp. Med. 1988, 167, 1697-1707. [CrossRef] [PubMed]

167. Holtfreter, S.; Roschack, K.; Eichler, P.; Eske, K.; Holtfreter, B.; Kohler, C.; Engelmann, S.; Hecker, M.; Greinacher, A.; Bröker, B.M. Staphylococcus aureus Carriers Neutralize Superantigens by Antibodies Specific for Their Colonizing Strain: A Potential Explanation for Their Improved Prognosis in Severe Sepsis. J. Infect. Dis. 2006, 193, 1275-1278. [CrossRef] [PubMed]

168. Bergdoll, M.S.; Crass, B.A.; Reiser, R.F.; Robbins, R.N.; Davis, J.P. A new staphylococcal enterotoxin, enterotoxin F, associated with toxic-shock-syndrome Staphylococcus aureus isolates. Lancet 1981, 1, 1017-1021. [CrossRef]

169. McCormick, J.K.; Yarwood, J.M.; Schlievert, P.M. Toxic shock syndrome and bacterial superantigens: An update. Annu. Rev. Microbiol. 2001, 55, 77-104. [CrossRef] [PubMed]

170. Rellahan, B.L. In vivo induction of anergy in peripheral $\mathrm{V}$ beta $8 \mathrm{~T}$ cells by staphylococcal enterotoxin $\mathrm{B}$. J. Exp. Med. 1990, 172, 1091-1100. [CrossRef] [PubMed]

171. Alderson, M.R.; Tough, T.W.; Davis-Smith, T.; Braddy, S.; Falk, B.; Schooley, K.A.; Goodwin, R.G.; Smith, C.A.; Ramsdell, F.; Lynch, D.H. Fas ligand mediates activation-induced cell death in human T lymphocytes. J. Exp. Med. 1995, 181, 71-77. [CrossRef] [PubMed]

172. Bachert, C.; Zhang, N.; Holtappels, G.; De Lobel, L.; van Cauwenberge, P.; Liu, S.; Lin, P.; Bousquet, J.; Van Steen, K. Presence of IL-5 protein and IgE antibodies to staphylococcal enterotoxins in nasal polyps is associated with comorbid asthma. J. Allergy Clin. Immunol. 2010, 126, 962-968.e6. [CrossRef] [PubMed]

173. Barnes, P.J. Intrinsic asthma: Not so different from allergic asthma but driven by superantigens? Clin. Exp. Allergy 2009, 39, 1145-1151. [CrossRef] [PubMed]

174. Gevaert, P.; Holtappels, G.; Johansson, S.G.O.; Cuvelier, C.; Cauwenberge, P.; Bachert, C. Organization of secondary lymphoid tissue and local IgE formation to Staphylococcus aureus enterotoxins in nasal polyp tissue. Allergy 2005, 60, 71-79. [CrossRef] [PubMed]

175. Zhang, N.; Holtappels, G.; Gevaert, P.; Patou, J.; Dhaliwal, B.; Gould, H.; Bachert, C. Mucosal tissue polyclonal IgE is functional in response to allergen and SEB. Allergy 2011, 66, 141-148. [CrossRef] [PubMed]

176. Bachert, C.; Zhang, N.; Patou, J.; van Zele, T.; Gevaert, P. Role of staphylococcal superantigens in upper airway disease. Curr. Opin. Allergy Clin. Immunol. 2008, 8, 34-38. [CrossRef] [PubMed]

177. Ragle, B.E.; Bubeck Wardenburg, J. Anti-alpha-hemolysin monoclonal antibodies mediate protection against Staphylococcus aureus pneumonia. Infect. Immun. 2009, 77, 2712-2718. [CrossRef] [PubMed]

178. Ragle, B.E.; Karginov, V.A.; Bubeck Wardenburg, J. Prevention and Treatment of Staphylococcus aureus Pneumonia with a $\beta$-Cyclodextrin Derivative. Antimicrob. Agents Chemother. 2009, 54, 298-304. [CrossRef] [PubMed]

179. Diep, B.A.; Le, V.T.M.; Visram, Z.C.; Rouha, H.; Stulik, L.; Castro Dip, E.; Nagy, G.; Nagy, E. Improved Protection in a Rabbit Model of Community-Associated Methicillin-Resistant Staphylococcus aureus Necrotizing Pneumonia upon Neutralization of Leukocidins in Addition to Alpha-Hemolysin. Antimicrob. Agents Chemother. 2016, 60, 6333-6340. [CrossRef] [PubMed]

180. Rouha, H.; Badarau, A.; Visram, Z.C.; Battles, M.B.; Prinz, B.; Magyarics, Z.; Nagy, G.; Mirkina, I.; Stulik, L.; Zerbs, M.; et al. Five birds, one stone: Neutralization of $\alpha$-hemolysin and 4 bi-component leukocidins of Staphylococcus aureus with a single human monoclonal antibody. MAbs 2015, 7, 243-254. [CrossRef] [PubMed]

(C) 2018 by the authors. Licensee MDPI, Basel, Switzerland. This article is an open access article distributed under the terms and conditions of the Creative Commons Attribution (CC BY) license (http://creativecommons.org/licenses/by/4.0/). 